\title{
UJI DAYA PROTEKSI EKSTRAK DAUN PEPAYA (Carica papaya L) DALAM SEDIAAN LOTION DENGAN BASIS PEG400 SEBAGAI REPELLENT TERHADAP AEDES AEGYPTI
}

\author{
Angger Luhung Nur Fadlilah ${ }^{1}$, Widya Hary Cahyati ${ }^{2}$, Rudatin Windraswara ${ }^{3}$ \\ 1,2,3 Jurusan Ilmu Kesehatan Masyarakat FIK Universitas Negeri Semarang \\ e-mail: widyahary27@mail.unnes.ac.id
}

\begin{abstract}
Dengue Hemorrbagic Fever (DHF) is spread by Aedes female mosquito. The popular efforts to control the vectors in the community is using chemical insecticides but can causing resistance to mosquitoes and toxicated for humans. This type of control can be in form of natural insecticides derived from plants, which is papaya leaves (Carica papaya L). The purpose of this study was to know the protection of the lotion from papaya leaf extract to repel Aedes aegypti. This type of study is true experimental with post test only control group design. Data were analyzed using Anova test and post hoc test. The research result is there a difference percentage of the number mosquitoes on various concentrations lotion of papaya leaf extract with $p=0.001$ ( $p<0.05)$. The result led to the conclusion that lotion of papaya leaf extract effectively repel Aedes aegypti at a concentration $30 \%$ because of the repel effect is more than $90 \%$.
\end{abstract}

Keywords: Aedes aegypti; Papaya Leaf Extract; Repellent.

\begin{abstract}
ABSTRAK
Demam Berdarah Dengue (DBD) ditularkan melalui gigitan nyamuk Aedes betina. Salah satu upaya pengendalian vektor yang populer di masyarakat yaitu menggunakan insektisida kimiawi akan tetapi menyebabkan resistensi pada nyamuk dan keracunan pada manusia. Upaya pengendalian dapat berupa insektisida alami yang terbuat dari tumbuhan, salah satunya yaitu daun pepaya (Carica papaya L). Tujuan dari penelitian ini adalah untuk mengetahui daya proteksi lotion ekstrak daun pepaya untuk menolak Aedes aegypti. Jenis penelitian ini adalah eskperimen murni dengan rancangan penelitian post test only control group design. Populasi penelitian adalah telur nyamuk Aedes aegypti yang dikembangbiakkan menjadi nyamuk, sampel 50 ekor nyamuk Aedes aegypti umur 2-5 hari untuk setiap kelompok perlakuan dengan 4 kali pengulangan, sehingga total nyamuk yang dibutuhkan 1.400 nyamuk Aedes aegypti karena jumlah perlakuan 7 kelompok. Data dianalisis menggunakan uji Anova dan Post Hoc. Hasil penelitian ini menunjukkan terdapat perbedaan persentase jumlah nyamuk yang hinggap pada berbagai konsentrasi lotion ekstrak daun pepaya dengan nilai signifikansi $\mathrm{p}=0,001(\mathrm{p}<0,05)$. Simpulan penelitian yaitu lotion ekstrak daun pepaya efektif menolak nyamuk Aedes aegypti pada konsentrasi 30\% karena daya tolaknya lebih dari 90\%.
\end{abstract}

Kata Kunci : Aedes aegypti; Ekstrak Daun Pepaya;Repellent. 


\section{PENDAHULUAN}

Demam Berdarah Dengue (DBD) merupakan penyakit yang disebabkan oleh virus dengue, yang masuk ke peredaran darah manusia melalui gigitan nyamuk dari genus Aedes, misalnya Aedes aegypti atau Aedes albopictus. Penyakit DBD ini dapat muncul sepanjang tahun dan menyerang seluruh kelompok umur. Penyakit DBD berkaitan dengan kondisi lingkungan dan perilaku yang dilakukan oleh masyarakat (Kemenkes RI, 2013). Kondisi rumah dan lingkungan yang tidak memenuhi syarat kesehatan merupakan faktor risiko sumber penularan berbagai jenis penyakit khususnya penyakit yang berbasis lingkungan salah satunya yaitu DBD (Cahyati, 2011). Kondisi rumah memegang peranan penting dalam munculnya DBD, berdasarkan penelitian yang dilakukan oleh (Cahyati, 2011) menunjukkan bahwa rumah yang terdapat jentik pada bak mandi memiliki risiko 2,612 kali lebih besar di banding rumah yang tidak terdapat jentik pada bak mandi.

Angka kesakitan DBD pada tahun 2013 terdapat 112.511 kasus dengan 871 kematian. Pada tahun 2014 ada 13.031 kasus dengan 1110 kematian (Kemenkes, 2014). Jumlah kasus baru di Jawa Tengah tahun 2011 mencapai 4.474 penderita, IR 13,77/100.000 penduduk, dan CFR DBD tahun 2011 sebesar 0,93\% (Dinkesprov Jateng, 2011). Dinas Kesehatan Kota Semarang mencatat pada tahun 2012 ada 1250 kasus dan ada 22 yang meninggal. Pada tahun 2013 jumlah penderita ada 780 kasus dan 7 yang meniggal (DKK Semarang, 2013). Pada tahun 2015 terdapat kasus DBD sebanyak 1737 dengan angka kesakitan / IR mencapai 98,61 / 100.000 penduduk, dengan kasus kematian adalah 21 orang dan CFR mencapai 1,21 \% turun dibandingkan dengan tahun 2014 (DKK Semarang, 2015). Kelompok umur yang rentan terkena DBD adalah anak-anak, hal tersebut dikarenakan faktor daya tahan tubuh yang masih rendah, dan aktivitas rutin sehari-hari yang rata-rata berada di dalam gedung atau ruang sekolah, mobilitas tinggi dan banyak bertemu dengan orang lain atau teman lain di sekolah atau tempat bermain. Kelompok umur $<12$ tahun memiliki daya tahan tubuh yang masih rendah dibandingkan kelompok umur yang lebih tua, sedangkan aktivitasnya sering bermain di luar selama beberapa jam atau bahkan hampir seharian berada di dalam kondisi dan waktu yang meningkatkan risiko terkena gigitan nyamuk penular DBD (Cahyati, 2016). 
Upaya penanggulangan dan pencegahan penyakit DBD sudah diatur dalam Perda No 5 Tahun 2010 tentang Pengendalian Penyakit DBD, upaya tersebut lebih difokuskan pada pengendalian vektornya yaitu pengendalian nyamuk Aedes aegypti. (Cahyati, 2016). Pengendalian nyamuk yang sering digunakan dikalangan masyarakat yaitu menggunakan anti nyamuk semprot, bakar, dan lotion anti nyamuk yang terbuat dari bahan-bahan kimia. Bahan kimia yang digunakan dalam anti nyamuk tersebut mempunyai dampak negatif seperti residu yang bahan aktifnya sulit terurai di alam. Penggunaan insektisida kimiawi apabila digunakan secara tepat sasaran, tepat dosis, tepat waktu, dan cakupan akan mampu mengendalikan vektor dan mengurangi dampak negatif terhadap lingkungan dan organisme yang bukan sasaran, salah satu contoh bahan yang digunakan yaitu tawas sebagai larvasida terhadap larva nyamuk Anopheles stephansi (Sulastri, 2016). Meskipun bisa digunakan sesuai standar, akan tetapi untuk mencegah dampak lebih lanjut dari efek penggunaan insektisida, maka perlu untuk mencari alternatif insektisida alami atau nabati.

Insektisida alami adalah suatu insektisida yang bahan dasarnya berasal dari alam. Jenis insektisida ini mudah terurai (biodegradable) di alam, sehingga tidak mencemarkan lingkungan dan relatif aman bagi manusia dan ternak, karena residunya akan terurai dan mudah hilang (Sugiata, 2011 dalam Mirnawaty, 2012). Penggunaan insektisida dirumah tangga memiliki beberapa keunggulan antara lain tidak meninggalkan residu pada lingkungan sehingga relatif lebih aman dibandingkan insektisida kimiawi, dan apabila meninggalkan residu, residu tersebut tidak menimbulkan resistensi pada sasaran karena lebih cepat terurai dibandingkan insektisida kimia.( Qinahyu, 2016).

Tanaman pepaya (Carica papaya L) merupakan salah satu komoditas besar yang ada di Indonesia dan memiliki kemampuan sebagai insektisida nabati pada larva dan nyamuk (Rehena, 2008). Uji fitokimia daun pepaya menggunakan spektrofotometry menghasilkan bahwa daun pepaya mengandung $0,25 \%$ alkaloid, 0,14\% flavonoid, $0,30 \%$ saponin dan $11,34 \%$ tanin. Uji fitokimia menggunakan Thin Layer Chromatography (TLC) menghasilkan bahwa daun pepaya juga mengadung $<68 \mathrm{mg} / \mathrm{ml}$ steroid, tetapi terpenoid negatif. Hal ini sejalan dengan penelitian yang dilakukan oleh A'yun (2015) dimana daun pepaya mengandung alkaloid, tripernoid, steroid,f lavonoid, 
saponin, and tanin. Penelitian lain juga menunjukkan bahwa daun pepaya mengandung flavonoid, fenol, alkaloid, dan asam amino (Cahyati, 2016). Kandungan kimia yang terdapat dalam daun pepaya seperti flavonoid, tanin, saponin, steroid, dan alkaloid berfungsi sebagai insektisida alami dan racun serangga (Cahyati, 2016).

Repellent adalah bahan kimia untuk menghindari gigitan dan gangguan serangga terhadap manusia. Cara memakai repellent bisa dioleskan atau disemprotkan. Repellent yang aman yaitu repellent yang tidak menggangu pemakai, tidak lengket, baunya menyenangkan, tidak beracun, dan tidak menimbulkan iritasi kulit. Bahan yang terdapat pada repellent yaitu DEET (Diethyltoluamide) yang merupakan repellent tidak berbau, tapi menimbulkan rasa terbakar jika mengenai mata, jaringan membranous, atau mengenai luka terbuka. Selain itu ada ethyl hexanediol yang efeknya berupa DEET (Dietbyltoluamide), tetapi waktu kerjanya pendek (Soedarto, 2011).

\section{METODE PENELITIAN}

Metode penelitian yang digunakan adalah metode penelitian rancangan eksperimental yaitu kegiatan percobaan yang bertujuan untuk mngetahui suatu pengaruh akibat adanya perlakuan tertentu (menggunakan lotion ekstrak daun pepaya sebagai repellent / penolak). Rancangan penelitian ini menggunakan desain studi eksperimen murni (true experiment). Pelaksanaan penelitian menggunakan rancangan post test only control group design yaitu tidak dilakukan pretes terhadap sampel sebelum perlakuan karena telah dilakukan randomisasi baik pada kelompok eksperimen dan kelompok kontrol.

Variabel bebas pada penelitian ini adalah berbagai konsentrasi lotion ekstrak daun pepaya (Carica papaya L) . Variabel terikat pada penelitian ini adalah jumlah nyamuk Aedes aegypti yang hinggap pada lengan yang diolesi lotion ekstrak daun papaya (Carica papaya L). Suhu diukur dengan cara menempatkan media uji pada ruangan yang tertutup sehingga suhunya stabil. Pengukuran suhu pada media tempat pengujian dari awal sampai akhir selama pengamatan. Pengukuran kelembaban menggunakan higrometer dilakukan dengan uji daya tolak dalam ruangan yang tertutup, sehingga akan memperoleh kelebaban yang stabil.. Umur nyamuk sangat berpengaruh pada daya tahan nyamuk terhadap pajanan insektisida, umur nyamuk yang digunakan dalam penelitian ini dalah 2-5 hari, karena 
pada umur tersebut ketahanan tubuh masih kuat dan produktif. Jenis kelamin nyamuk yang digunakan yaitu Aedes aegypti betina sebagai sampel, karena nyamuk yang menghisap darah adalah nyamuk betina. Jumlah nyamuk yang digunakan dalam penelitian sejumlah 50 ekor nyamuk. Lama waktu kontak setiap perlakuan 5 menit.

Populasi penelitian adalah telur nyamuk Aedes aegypti yang dikembangbiakkan menjadi nyamuk di Laboratorium Rearing Balai Penelitian dan Pengembangan Penyakit Bersumber Binatang (P2B2) Banjarnegara. Besar sampel penelitian adalah 50 ekor nyamuk Aedes aegypti umur 2-5 hari untuk setiap kelompok perlakuan dengan 4 kali pengulangan, sehingga total nyamuk yang dibutuhkan 1.400 nyamuk Aedes aegypti karena jumlah perlakuan 7 kelompok. Pengambilan sampel dilakukan secara acak sederhana (simple random sampling) karena anggota populasi bersifat homogen atau diasumsikan homogen.

Proses ekstrasi daun papaya (Carica papaya L) dilakukan di Laboratorium Biologi FMIPA Unnes dengan metode maserasi. Kemudian dibuat dalam sediaan lotion dengan bahan-bahan campuran seperti setil alkohol, asam stearat, PEG400, dan metil paraben. Kemudian ditambah bahan lain seperti trictanolamin, gliserin, dan minyak atsiri selanjutnya ditambah aquades sedikit demi sedikit (Manaf, 2012). Daun pepaya (Carica papaya L) yang digunakan daun yang sudah tua dan juga muda. Daun ini didapatkan dari Ungaran Kabupaten Semarang.

Pengujian lotion ekstrak daun papaya (Carica papaya L) dilakukan di Instalasi entomologi P2B2 Banjarnegara. Pengulangan dilakukan sebanyak 4 kali yang diperoleh dengan menggunakan rumus: $(\mathrm{t})(\mathrm{r})-1 \geq 15$. Tahap pengujian dengan menyiapkan kandang uji, tiap kandang dimasukkan nyamuk 50 ekor. Kemudian lengan kiri diolesi lotion ekstrak daun pepaya (Carica papaya L) sebagai perlakuan dan lengan kanan tidak diolesi lotion, dan dipaparkan selama 5 menit, hitung jumlah nyamuk yang hinggap selama pemaparan baik lengan kiri maupun kanan. Pengujian dilakukan selama 6 jam dibagi dalam 6 periode, 1 jam per periode dengan 5 menit pemaparan. Setiap kali ada nyamuk yang lumpuh diganti dengan nyamuk segar. Suhu tubuh probandus maupun suhu dan kelembaban udara diukur tiap jam selama pengujian. Konsentrasi yang digunakan adalah konsentrasi ekstrak daun pepaya (Carica papaya L) 5\%, 10\%, 15\%, 20\%, 
$25 \%$, dan $30 \%$ ditambah kontrol positif lotion nyamuk merek x dengan bahan aktif Diethyltoluamide 13\%. Pengumpulan data dilakukan dengan cara menghitung jumlah nyamuk yang hinggap selama perlakuan 6 jam. Uji statistik yang digunakan adalah uji one way anova untuk mencari perbedaan jumlah rata-rata nyamuk yang hinggap pada lengan dengan konsentrasi tertentu.

Instrumen yang digunakan dalam penelitian ini adalah 1) lembar observasi untuk memperoleh data jumlah nyamuk yang hinggap pada lengen kontrol dan lengan perlakuan; 2) termometer dan higrometer untuk mengukur suhu dan kelembaban ruang pada saat penelitian; 3) lotion ekstrak daun pepaya yang diuji untuk menurunkan jumlah nyamuk yang hinggap pada lengan.

Data yang terkumpul diolah dan dianalisis dengan menggunakan program komputer analisis univariat dilakukan untuk mendeskripsikan setiap variabel dengan cara membuat tabel dan grafik distribusi frekuensi. Analisis bivariat digunakan untuk mencari hubungan antar variabel. Penelitian ini menggunakan uji Anova dan Post Hoc untuk mengetahui ada tidaknya perbedaan jumlah nyamuk yang hinggap antar konsentrasi lotion ekstrak daun pepaya dan juga dengan kontrol positif yang digunakan yaitu lotion dengan dietbyltoluamide $13 \%$.

\section{HASIL}

Berikut ini hasil pengamatan daya proteksi lotion ekstrak daun pepaya (Carica papaya L).Berdasarkan data dari Tabel 1 diperoleh data yang menunjukkan rata-rata daya proteksi dari lotion ekstrak daun pepaya (Carica papaya L) selama 6 jam pengamatan. Dari data tersebut diketahui daya proteksi total tertinggi yaitu pada lotion ekstrak daun pepaya (Carica papaya L) dengan konsentrasi 30\% yaitu sebesar 91,3\%, sedangkan untuk daya proteksi total terendah adalah lotion ekstrak daun pepaya dengan konsentrasi $5 \%$ yaitu sebesar $55,8 \%$.

\section{PEMBAHASAN}

Hasil penelitian ini menunjukkan bahwa nilai konsentrasi yang efektif adalah pada konsentrasi 30\%, karena daya tolak nyamuk pada lengan yang diolesi lotion ektrak daun pepaya (Carica papaya L) lebih dari $90 \%$ sejalan dengan Komisi Pestisida Departemen Pertanian (1995) mensyaratkan bahwa repellent nyamuk dapat dikatakan efektif apabila daya proteksinya minimal 90\% (Kardinan, 2007). 
Berdasarkan hasil penelitian pada nyamuk Aedes aegypti jumlah rata-rata yang hinggap pada lengan kanan (kontrol) lebih banyak dibandingkan dengan lengan sebelah kiri (perlakuan). Hal itu dikarenakan lengan kanan tidak diolesi lotion ekstrak daun pepaya, sedangkan lengan sebelah kiri diolesi lotion ekstrak daun papaya

Tabel 1. Hasil Pengamatan Daya Proteksi

\begin{tabular}{cccccccc}
\hline Konsentrasi & \multicolumn{6}{c}{ Rata-rata Daya Proteksi (\%) Pada Jam Ke- } \\
\cline { 2 - 8 } $\begin{array}{c}\text { Ekstrak Daun } \\
\text { Pepaya (\%) }\end{array}$ & I & II & III & IV & V & VI & DP Total \\
\hline $5 \%$ & 64,2 & 55 & 50 & 52,2 & 56 & 45,8 & 55,8 \\
$10 \%$ & 69,5 & 68,3 & 60,7 & 66,3 & 68 & 71,5 & 67,3 \\
$15 \%$ & 56 & 64,5 & 54 & 63 & 56 & 66,8 & 59,2 \\
$20 \%$ & 75,7 & 77 & 82,8 & 72 & 60,2 & 70 & 73,8 \\
$25 \%$ & 82,6 & 61,4 & 73 & 84,2 & 73,4 & 78,4 & 75,7 \\
$30 \%$ & 90 & 89,6 & 100 & 95 & 92,4 & 86,2 & 91,3 \\
Lotion $X$ & 78,9 & 90,9 & 94,9 & 92,8 & 87 & 86,7 & 87,4 \\
\hline
\end{tabular}

Sumber: Data hasil penelitian, 2017

Daya proteksi ekstrak daun pepaya setiap konsentrasi mengalami kenaikan dan penurunan. Hal ini disebabkan oleh beberapa faktor diantaranya ketahanan ekstrak tersebut tidak cukup lama dan berkurang setiap jamnya. Berkurangnya daya tahan dari aroma ekstrak tersebut dapat disebabkan besarnya laju penguapan selama pengujian berlangsung pada setiap waktu pengamatan. Semakin turun daya proteksinya maka semakin rendah daya tolak dari ekstrak daun pepaya. Perubahan potensi lotion ekstrak daun pepaya dari jam ke jam dipengaruhi oleh dua hal, yang pertama adalah penguapan senyawa-senyawa kimia yang terdapat dalam ekstrak daun pepaya yang semakin meningkat seiring berjalannya waktu, sehingga bau dari ekstrak daun pepaya akan hilang dan mengakibatkan penurunan potensi repellent. Yang kedua adalah aktivitas nyamuk Aedes aegypti yang semakin menurun seiring bertambahnya waktu, sehingga seakan-akan nyamuk yang hinggap pada lengan semakin sedikit. Penurunan aktivitas nyamuk tersebut disebabkan oleh perbedaan umur dan keadaan oviparitas dari masingmasing nyamuk (Kardinan, 2007).

Penyebab nyamuk tidak mendekat karena adanya kontak dengan lotion daun pepaya memiliki aroma khas yang tidak disukai oleh nyamuk, karena aroma tersebut mengganggu proses fisiologis reseptor kimia yang terdapat pada antena. Proses 
tersebut kemudian akan diubah menjadi impuls, dan diteruskan oleh akson syaraf ke syaraf pusat, kemudian akan terjadi integrasi pada syaraf motorik ke otak sehingga nyamuk menghindar (Syalfinaf, 2012). Tingkah laku nyamuk pada saat mencari makanan dipengaruhi oleh berbagai rangsangan yang dikeluarkan oleh sumber makanan (manusia, hewan), yaitu kehangatan, kelembaban, bau, ada tidaknya $\mathrm{CO}_{2}$ dan rangsangan visual. Nyamuk lebih suka suasana hangat dan menyukai tangan yang kurang memancarkan uap air. Nyamuk lebih menyukai $\mathrm{CO}_{2}$ dan warna kulit yang gelap dibandingkan yang terang.

Daun pepaya (Carica papaya L) merupakan tanaman yang sangat potensial, murah, mudah didapat, dan belum banyak dimanfaatkan. Uji fitokimia daun pepaya menggunakan spektrofotometry menghasilkan bahwa daun pepaya mengandung $\quad 0,25 \%$ alkaloid, $\quad 0,14 \%$ flavonoid, $0,30 \%$ saponin, dan $11,34 \%$ tanin. Uji fitokimia menggunakan Thin Layer Chromatography (TLC) menghasilkan bahwa daun pepaya juga mengandung $<68 \mathrm{mg} / \mathrm{ml}$ steroid, tetapi terpenoid negatif. Hal ini sejalan dengan penelitian yang dilakukan oleh (A'yun , 2015) dimana daun pepaya mengandung alkaloid, tripernoid, steroid, flavonoid, saponin, and tanin. Penelitian lain juga menunjukkan bahwa daun pepaya mengandung flavonoid, fenol, alkaloid, dan asam amino (Cahyati, 2016). Kandungan kimia yang terdapat dalam daun pepaya seperti flavonid, tanin, saponin, steroid dan alkaloid berfungsi sebagai insektisida alami dan racun serangga (Cahyati, 2016).

Salah satu senyawa kimia yang mempunyai fungsi sebagai insektisida yaitu flavonoid. Flavonoid bekerja menghambat mitokondria dalam sel, sedangkan mitokondria tersebut berfungsi sebagai tempat terjadinya proses respirasi yaitu transport elektron dan siklus kerbs. Dimana transport elektron dan siklus kerbs pada mitokondria itu berperan dalam metabolisme energi dan pembentukan ATP (Adenosin Tri Fosfat). Jika pada mitokondria terganggu, maka produksi ATP akan terhambat, sehingga pengikatan terhadap oksigen rendah pada akhirnya penggunaan oksigen oleh mitokondria tidak maksimal maka menyebabkan gangguan pada pernafasan. (Qinahyu, 2016).

Berdasarkan penelitian, dapat disimpulkan bahwa lotion ekstrak daun pepaya (Carica papaya L) efektif sebagai 
repellent karena kandungan zat aktif yang ada pada daun pepaya tersebut dapat mempengaruhi jumlah rata-rata nyamuk yang hinggap pada lengan. Konsentrasi yang efektif saat pengujian yaitu pada konsentrasi 30\% dengan daya proteksi 91\%. Penelitian lebih lanjut untuk mengembangkan lotion anti nyamuk bebahan daun pepaya diperlukan dengan pertimbangan lotion anti nyamuk ini sebagai repellent atau insektisida nabati, sehingga lebih aman untuk bisa digunakan di masyarakat dibandingkan dengan insektisida sintetik atau kimiawi.

Insektisida nabati merupakan insketisida yang berbahan dasar dari tanaman. Insektisida nabati biasanya tidak hanya mengandung satu macam bahan aktif, tetapi beberapa jenis bahan aktif (Manaf, 2012). Senyawa yang terkandung dalam tumbuh-tumbuhan dapat berpengaruh terhadap serangga hama melalui beberapa mekanisme seperti penghambat nafsu makan, repellent (penolak), menghambat perkembangan, menurunkan reproduksi, dan sebagai racun (Hersanti, dkk,2013).

Penggunaan insektisida alami atau nabati di masayarakat merupakan suatu potensi dan alternatif pemecahan masalah yang perlu dikembangkan. Beberapa keunggulan yang bisa didapat dari penggunaan insektisida nabati itu sendiri yaitu tidak meninggalkan residu pada lingkungan sehingga relatif aman bila dibandingkan dengan insektisida kimiawi atau sintetis.

\section{KESIMPULAN}

Berdasarkan hasil penelitian dapat disimpulkan konsentrasi yang paling efektif adalah konsentrasi 30\% dengan rata - rata daya proteksi selama enam jam sebesar 91\%. Terdapat perbedaan persentase jumlah nyamuk Aedes aegypti yang hinggap pada berbagai konsentrasi lotion ekstrak daun pepaya yaitu 5\%,10\%, $15 \%, 20 \%$, 25\% dan 30\%. Saran yang diberikan peneliti adalah masyarakat sebagai konsumen agar dapat mempertimbangkan sebagai alternatif pemanfaatan bahan-bahan alami seperti daun pepaya dalam upaya pengendalian vektor nyamuk. Perlu adanya penelitian lebih lanjut untuk menganalisis faktor waktu penyimpanan ekstrak dan bahan aktif yang terkandung dalam daun pepaya beserta karakteristik zat tersebut untuk dikembangkan menjadi lotion anti nyamuk. Bagi instansi kesehatan bekerja sama dengan lembaga penelitian dan departemen pertanian untuk mengembangkan hasil penelitian ini sebagai pengendalian nyamuk alami yang 
dapat direkomendasikan kepada masyarakat.

\section{UCAPAN TERIMAKASIH}

Ucapan terima kasih kami sampaikan kepada Kepala Laboratorium Biologi FMIPA Unnes, Teknisi Laboratorium Biologi FMIPA Unnes, Kepala B2P2VRP Salatiga, serta Kepala Balai Litbang P2B2 Banjarnegara.

\section{REFERENSI}

Cahyati, W.H, dan Sulastri. (2016). Dosis Konsentrasi Tawas (Al2(SO4)3) Terhadap Kematian Larva Aedes aegypti. Jurnal Care. Vol.4, No.2: $1-7$.

Cahyati, W.H, Widya Asmara, S.R Umniyati, dan B.Mulyaningsih. (2017). The Pthytochemical Analysis Of Hay Infusions and Papaya Leaf Juice As An Attractant Containing Insecticide For Aedes aegypti. Jurnal Kemas 12(2): 96-101

Cahyati, W.H dan Tur Endah Sukowinarsih.(2010). Hubungan Sanitasi Rumah dengan Angka Bebas Jentik Aedes aegypti. Jurnal Kemas. Vol.6,No.1:30-35

Cahyati, W.H, D.M.Sukendra, Yunita D.P.Santik. (2016). Penurunan
Container Index (CI) Melalui Penerapan Ovitrap di Sekolah Dasar Kota Semarang. Unnes Journal of Public Health, Vol.5,No.4: 330-334.

Hersanti, Santosa, E., \& Dono, D.(2012).Pelatihan Pembuatan Pestisida Alami untuk Mengendalikan Hama dan Penyakit Tanaman Padi di Desa Tenjolaya dan Desa Sukamelang, Kecamatan Kasomalang, Kabupaten Subang, Jurnal Aplikasi Ipteks untuk Masyarakat, Vol. 2, No. 2, November: 139 145.

Kardinan, Agus. (2007). Potensi Selasih Sebagai Repellent Terhadap Nyamuk Aedes aegypti. Jurnal Litri $13(2): 38-42$.

Kementerian Kesehatan Republik Indonesia. (2013). Profil Kesehatan Indonesia 2013. Diperoleh dari http://www.depkes.go.id/resourc es/download/pusdatin/buletin/b uletindbd.Pdf.

Manaf, Syalfinaf, Helmiyetti dan Ely Gustiyo. (2012). Efektivitas Minyak Arsiri Daun Kemangi ( Ocium basillicum) sebagai Bahan Aktif Losion Antinyamuk Aedes 
aegypti L. Konservasi Hayati Vol. 08 No. 02:27-32 ISSN 0216-9487

Mirnawaty, Supriadi, dan Budiman Jaya. (2012). Uji Efektivitas Ekstrak Kulit Langsat (Lansium domesticum) sebagai Anti Nyamuk Elektrik Terhadap Nyamuk Aedes aegypti. J. Akad. Kim. 1(4): 147-152, November 2012 ISSN 2302-6030.

Qinahyu, W.D, dan Widya Hary Cahyati. (2016). Uji Kemampuan Anti Nyamuk Alami Elektrik Mat
Serbuk Bunga Sukun (Artocarpus altilis) di Masyarakat. Jurnal Care, Vol.4, No.3: 9-18.

Rehena, JF. 2008. Pengaruh Ekstrak Daun Pepaya Terhadap Pertumbuhan Parasit Malaria dan Sosialisasinya. Jurnal Ilmu Dasar.Vol.11 No.1, Januari 2010:96-100

Soedarto. 2011. Buku Ajar Parasitologi Kedokteran. Jakarta: CV Sagung Seto 